\title{
Bioconversion of organic solid wastes into biofortified compost using a microbial consortium
}

\author{
Payel Sarkar $^{1} \cdot$ Rounak Chourasia $^{1}$
}

Received: 11 May 2017/Accepted: 14 October 2017/Published online: 30 October 2017

(c) The Author(s) 2017. This article is an open access publication

\begin{abstract}
Purpose Urban municipal solid waste in India are $75-85 \%$ organic. Uncontrolled dumping of this waste is a major health concern. Degradation of organic waste by use of a microbial consortium is safe, efficient and economic. Therefore, this study was taken up to recycle the organic solid waste into effective compost using a microbial consortium.

Methods Bacterial consortia were developed using antagonism assay. Concomitant enzyme production by the consortia was determined. The best consortium was further employed for degradation of $30 \mathrm{~kg}$ of organic solid waste. Compost analysis of $30 \mathrm{~kg}$ of wastes was done to determine the level of C, N, K, P and S.

Results In this study, of the four consortia proposed, consortia no. 2 had the highest degrading capability. It exhibited consistent degrading capabilities of $30 \mathrm{~kg}$ waste. The volume of the waste was reduced to $82 \%$, with a reduction in mass and moisture content to 65 and $42 \%$, respectively, after 30 days of degradation study. The compost produced after 30 days had a dark colour and grainy texture without any crustacean population and lacked foul smell. Compost analysis of $30 \mathrm{~kg}$ wastes inoculated with consortium 2 showed C:N ratio of 22:1 compared to 32:1 in control, and increased percentage of $\mathrm{K}, \mathrm{P}$ and $\mathrm{S}$ which are required for enhancement of soil fertility.
\end{abstract}

Payel Sarkar

payal.jobs83@gmail.com

1 Department of Microbiology, University of North Bengal, Raja Rammohunpur, Siliguri, West Bengal 734013, India
Conclusion Therefore, we can conclude that consortium 2 can serve as a biological tool for the removal of organic solid wastes from the environment, and the compost generated from the degradation can be applied to increase the fertility of the soil.

Keywords Municipal solid waste $\cdot$ Microbial consortium · Compost - Soil fertility

\section{Introduction}

Biodegradable waste refers to the amount of organic matter in waste. Biodegradable waste is commonly found in municipal solid waste (MSW) where the organic matter in waste ranges from 75 to $85 \%$ in urban MSWs of India. The varying content of organic matter in waste depends on the economic condition of the country from where it is generated (Bandara et al. 2007). Recent decades had seen rapid increase in human population, accelerating economy and urbanization, which have led to an exponential increase in waste generation every year (Gouveia and Prado 2009). According to Gupta and Arora (2016), it has been estimated that urban India generates approximately $1,88,500$ tonnes of municipal solid waste per day ( 68.8 million tonnes per year). The most common and cheap waste disposal technique involves dumping of waste in a specified disposal yard. This results in the pollution of soil by toxic chemicals present in waste, leading to emergence of diseases in plants, human beings and cattle (Forastiere et al. 2011).

Thus, micro-organisms present in soils of dump sites are exposed to varied substrates and chemicals, which raises the possibility of screening effective bacterial strains with valuable applications. Rapid organic waste degradation 
requires the action of micro-organisms with enhanced enzyme activity to break down complex polymers into simpler degradable molecules. Therefore, inoculation of waste with microorganisms that produce extracellular enzymes such as cellulase, amylase, protease, pectinase and lipase at higher levels enhances waste degradation, thus helping in keeping up of the waste degradation rate to that of waste dumping (Saha and Santra 2014).

This requirement is fulfilled with the co-operation of many micro-organisms, each of which contributes in secreting different enzymes. The degradation of organic waste by use of a microbial consortium is considered highly efficient, and the capability of waste degradation by a consortium depends on its functional and structural stability (Mirdamadian et al. 2011). The stability of a potential waste-degrading consortium can be observed by testing antagonistic (competition for substrate among different microbes present in the consortium) and synergistic (co-operation between different microbes present in the consortium for better degradation of wastes) activities within the strains and testing the concomitant production of different enzymes by the bacterial strains within the consortium to study the consortium's functioning under natural conditions of substrate availability (Sarkar et al. 2011).

Therefore, the main objective of this present study was to develop a microbial consortium that can act as a biological tool for removal of organic solid wastes from the environment and application of the compost generated from the degradation to increase the fertility of the soil.

\section{Materials and methods}

\section{Collection of samples}

Soil samples were collected from the dumping land of Matigarahat (latitude-26 $85^{\prime} \mathrm{N}$, longitude- $88^{\circ} 44^{\prime} \mathrm{E}$, Siliguri, Darjeeling District, West Bengal, India) in sterile 'Whirl-Pak' plastic maintaining aseptic conditions and immediately transported to the laboratory for further tests.

\section{Characterization of the soil sample}

\section{Determination of moisture content (\%) in soil samples}

The soil sample was taken in a pre-weighed container and the initial weight was recorded. The sample was dried in a hot air oven at a temperature of $110{ }^{\circ} \mathrm{C}$ while weighing the sample at regular intervals until a constant weight was achieved. The moisture content of the sample was calculated using the following Eq. (1) (AWPA 1986):
$\operatorname{MC}(\%)=\frac{W-w}{w} \times 100$

where $\mathrm{MC}$ is the moisture content, $W$ the original weight and $w$ the constant weight after oven drying.

\section{Chemical analysis of soil samples}

The chemical characteristics of the soil sample were tested for the following parameters: $\mathrm{pH}$, organic carbon (\%), nitrogen $(\%)$, potassium (ppm), phosphorus (ppm), sulphur (ppm), organic matter (\%) and electrical conductivity (EC). Organic carbon, nitrogen content, phosphorus, sulphur and potassium were determined using the rapid titration method (Walkey and Black 1934), Kjeldahl procedure (Bremner 1960), barium chloride colorimetric method (Jackson 1973) and flame photometric method after ammonium acetate extraction (Toth and Prince 1949). The $\mathrm{pH}$ was determined using a digital $\mathrm{pH}$ meter.

\section{Isolation of bacteria from the soil sample}

Isolation of bacteria from the soil sample was done from the waste dumping land of Matigarahat (latitude $-26^{\circ} 85^{\prime} \mathrm{N}$, longitude $-88^{\circ} 44^{\prime}$ E) Siliguri, West Bengal, India, by the serial dilution method. $1 \mathrm{~g}$ of the soil sample was added to a test tube containing sterile $10 \mathrm{ml}$ deionized water. This tube was marked as stock. It was shaken vigorously to dissolve the soil and form a homogenized solution, followed by subsequent tenfold dilution by transferring $1 \mathrm{ml}$ solution to sterile $9 \mathrm{ml}$ deionized water-containing tubes until a dilution of $10^{-6}$ was obtained. $0.1 \mathrm{ml}$ of the solution from last three dilution was transferred to sterile nutrient agar culture media plates $(\mathrm{pH} 7)$ via the spread plate method and incubated at $37{ }^{\circ} \mathrm{C}$ for $24 \mathrm{~h}$. Bacterial colonies were selected on the basis of colony morphology and pigmentation. The isolated colonies were purified by streaking and preserved in slants at $4{ }^{\circ} \mathrm{C}$.

\section{Screening of bacteria for the production of extracellular enzymes and morphological characterization}

The isolated strains were further characterized on the basis of their substrate specificity (starch, cellulose, casein, pectin, tributyrin) and gram character. The inoculated plates were incubated overnight at $37{ }^{\circ} \mathrm{C}$ and checked for a zone of clearing around each bacterial isolate. For starch agar, the zone of clearing was observed after flooding the plates with iodine. Cellulase-producing organisms were detected by flooding the plates with $0.1 \%$ Congo Red for $20 \mathrm{~min}$, followed by rinsing with $1 \mathrm{M} \mathrm{NaCl}$. Caseinasepositive bacterial isolates will show clear halo zone around 
the culture growth in skimmed milk agar. Pectinase-positive bacterial isolates will show clear zones around culture growth due to lack of formation of the pectin-iodine complex after flooding with iodine. Lipase-positive isolates show a clear zone around bacterial growth that was observed due to the hydrolysis of tributyrin.

\section{The proposed combination of the consortium}

Four different microbial consortia were prepared by permutation and combination, keeping in mind their concomitant enzyme production and gram character. The compatibility of the bacterial strains within the consortia was checked by antagonism assay.

\section{Antagonism of bacterial strains}

The cross streaking method was used to test the antagonism among the selected bacterial strains before consortium preparation. Each bacterial culture $(24 \mathrm{~h})$ was inoculated in sterile nutrient agar media plates as a $1.5 \mathrm{~cm}$-wide streak (wider streak to obtain larger inhibitory zone in case of antagonism) diametrically across the plate and incubated at $37^{\circ} \mathrm{C}$ for $24 \mathrm{~h}$. After incubation, indicator organisms (to be present in the potential consortium) were streaked at right angle to the original inoculum. This process was followed to test each organism's antagonism against the other members of the consortium.

\section{Concomitant enzyme production by the consortium}

Each consortium was inoculated (1\% inoculum load) in $50 \mathrm{ml}$ synthetic media: modified Czapek mineral-salt broth [(g/l) sodium nitrate 2 , potassium chloride 0.5 , magnesium sulphate 0.5 , di-potassium hydrogen phosphate 1 , ferrous sulphate 0.01 supplemented with $\mathrm{CMC}$, pectin, starch, skimmed milk and tributyrin $(0.5 \%$ each $)]$ and incubated at $37{ }^{\circ} \mathrm{C}$ at $150 \mathrm{rpm}$ for 7 days (Sarkar et al. 2011). After every $24 \mathrm{~h}, 6 \mathrm{ml}$ of the sample was withdrawn from the broth and centrifuged at $10,000 \mathrm{rpm}$. The supernatant was subjected to amylase, cellulase, protease, pectinase and lipase enzyme assays.

\section{Amylase assay}

Amylase activity was determined by the DNS method. 1\% starch solution was prepared in $50 \mathrm{mM}$ phosphate buffer (pH7) and used as substrate. The substrate, crude enzyme and buffer were added to tubes and incubated at $37{ }^{\circ} \mathrm{C}$ for $30 \mathrm{~min}$. After incubation, the contents of the enzyme blank were added, $1 \mathrm{ml}$ DNS reagent added to all test tubes and all the solutions in the tubes were boiled for $5 \mathrm{~min}$. The tubes were allowed to cool to room temperature and then diluted with $5 \mathrm{ml}$ distilled water. Absorbance was measured at $540 \mathrm{~nm}$ and the glucose standard curve was prepared using different glucose dilutions. One unit of enzyme activity is defined as the amount of enzyme that releases $1 \mu \mathrm{mol}$ of reducing sugar (glucose) per minute under assay conditions $(\mathrm{U} / \mathrm{ml} / \mathrm{min})$.

\section{Cellulase activity}

Cellulase activity was determined by the DNS method. $1 \%$ CMC solution was prepared in $50 \mathrm{mM}$ phosphate buffer (pH7) and used as the substrate. The substrate crude enzyme and buffer were added to tubes similar to the amylase assay. The assay was conducted following a similar protocol to the amylase assay under the same incubation temperature and time. Absorbance was measured under $540 \mathrm{~nm}$. Glucose standard curve was used as standard. One unit of enzyme activity is defined as the amount of enzyme that releases $1 \mu \mathrm{mol}$ of reducing sugar per minute under assay conditions (U/ml/min).

\section{Protease assay}

Protease activity was determined spectrophotometrically following the protocol of Sigma's universal protease activity assay. Casein was used as a substrate and the ability of the enzyme to digest casein into tyrosine was tested. $1 \%$ casein was prepared in $50 \mathrm{mM}$ potassium phosphate buffer ( $\mathrm{pH}$ 7.5) and used as substrate. The substrate, crude enzyme and buffer were added to tubes and incubated at $37{ }^{\circ} \mathrm{C}$ for $10 \mathrm{~min}$. After incubation, the contents of the enzyme blank were added and to all the tubes $0.5 \mathrm{ml}$ stopping agent trichloroacetic acid (TCA) (20\% w/v) was added. The tubes were incubated at $37{ }^{\circ} \mathrm{C}$ for $30 \mathrm{~min}$. After the incubation period, the content of each tube was centrifuged at $10,000 \mathrm{rpm}$ for $10 \mathrm{~min}$ to separate insoluble substances from the sample. $1 \mathrm{ml}$ of the supernatant was taken in a fresh test tube to which $5 \mathrm{ml}$ of $0.5 \mathrm{M}$ sodium carbonate was added, followed by the quick addition of $0.5 \mathrm{ml}$ Folin-Ciocalteu reagent. The tubes were kept in dark for $20 \mathrm{~min}$. Absorbance was recorded at $660 \mathrm{~nm}$. One unit of enzyme activity is defined as the amount of enzyme that releases $1 \mu \mathrm{mol}$ of tyrosine per minute under assay conditions $(\mathrm{U} / \mathrm{ml} / \mathrm{min})$.

\section{Pectinase assay}

Pectinase activity was determined titrimetrically following standard Sigma protocol using pectin as the substrate. $0.5 \%$ pectin solution was prepared in distilled water. This solution was used as the substrate. $4.90 \mathrm{ml}$ of the substrate was taken in flaks marked as test and blank and kept at room temperature for $5 \mathrm{~min} .0 .1 \mathrm{ml}$ of crude enzyme was added 
to test flasks, mixed thoroughly and the flasks along with the blank were incubated at room temperature for $5 \mathrm{~min}$. After incubation, $5 \mathrm{ml} 0.1 \mathrm{~N}$ iodine and $1 \mathrm{ml} 1 \mathrm{M}$ sodium carbonate were added to the solution, which was incubated at room temperature for $5 \mathrm{~min}$. Then, $2 \mathrm{ml} 2 \mathrm{~N}$ sulphuric acid was added, mixed well and the flasks were kept in dark for $20 \mathrm{~min}$. Titration of the dark brown solution was done by $0.1 \mathrm{M}$ sodium thiosulphate until the solution turned faint yellow in colour. Here, one drop of $1 \%$ starch solution was added to obtain a dark blue colour and then the solution was finally titrated until the solution turned colourless. One unit of enzyme activity is defined as the amount of enzyme that releases $1 \mu \mathrm{mol}$ galacturonic acid per minute under assay conditions using Eq. (2):

Units/ml enzyme

$=\frac{(\mathrm{ml} \text { of titrant for blank }-\mathrm{ml} \text { of titrant for test }) \times 1 \times d f \times 100}{0.100 \times 5 \times 2}$,

where $d f=$ dilution factor, $1=$ one micromole of galacturonic acid is oxidized by 1 micro-equivalent of $I_{2}$, $100=$ micro-equivalents of $\mathrm{S}_{2} \mathrm{O}_{3}$ per millilitre of titrant, $0.100=$ volume (in millilitre) of enzyme used in enzymatic reaction, 2 micro-equivalents of $\mathrm{S}_{2} \mathrm{O}_{3}$ oxidized per micro-equivalent of $I_{2}$ reduced and $5.0=$ time of incubation of assay in minutes per unit definition.

\section{Lipase assay}

Lipase activity was determined titrimetrically using tributyrin oil as the substrate. $1 \mathrm{ml}$ of tributyrin was mixed with $3 \mathrm{ml} 50 \mathrm{mM}$ Tris- $\mathrm{HCl}$ buffer (pH8) and an emulsion was formed by swirling the contents. $1 \mathrm{ml}$ of the crude enzyme was added to the emulsion ( $1 \mathrm{ml}$ buffer in blank) and incubated at $37{ }^{\circ} \mathrm{C}$ for $30 \mathrm{~min}$. After incubation of one drop of the indicator, $1 \%$ phenolphthalein solution was added to both test and blank and titrated with $50 \mathrm{mM}$ sodium hydroxide until a pale pink colouration was developed. One unit of enzyme activity is defined as the amount of enzyme that releases $1 \mu \mathrm{mol}$ of fatty acid per minute under assay conditions.

\section{Determination of organic waste degradation (laboratory trials with $5 \mathrm{~kg}$ of wastes)}

The ability of the consortia to degrade $5 \mathrm{~kg}$ of organic wastes was determined by individually inoculating $5 \%(\mathrm{v} /$ v) consortium ( $24 \mathrm{~h}$ old cultures) in two sets of organic wastes collected from canteens around North Bengal University. The consortium was mixed evenly and kept in normal conditions for a month to observe the degradation. The heaps were mixed periodically to maintain aeration. A third set of uninoculated organic wastes was kept under similar experimental conditions that served as control. The sample was withdrawn periodically at a constant interval of 7 days till 28 days and waste degradation was measured on the basis of the following parameters.

\section{Determination of waste volume}

The buckets used for the trials have the shape of truncated cone and thus the volume of the bucket was calculated using Eq. (3):

Volume $=\pi / 3 h\left(R^{2}+\mathrm{Rr}+r^{2}\right)$

where $h$ is the height of the bucket, $R^{2}$ the radius of the upper surface of the bucket, $\mathrm{Rr}$ the radius of the middle of the bucket and $r$ the radius of the bottom of the bucket.

The volume of the waste was calculated accordingly at an interval of 7 days with respect to the bucket as the waste level decreased due to degradation.

\section{Determination of waste density}

Density of the waste was determined by filling a Petri dish full of the waste sample and weighing the content. The volume of the Petri plate was determined using the formula of the volume of the cylinder. Then the formula for density ( $\rho=$ mass/volume) was used.

\section{Determination of waste mass}

Mass of the degrading waste was determined after 7 days for a month with the data obtained from density and volume of the waste at the respective day, using the formula for density.

\section{Change in temperature}

Temperature changes were observed at three levels: top surface, centre and bottom. This was done by making holes in the wall of the bucket to observe temperature gradations of the three levels with respect to the degradation.

\section{Determination of moisture content in waste}

Waste degradation is associated with reduction in moisture content. Moisture content estimation was similar to the protocol followed during moisture content analysis of the soil.

\section{Physical observation of waste}

After 30 days of inoculation, wastes were observed for changes in colour and odour. After conducting the degradation study for 30 days with $5 \mathrm{~kg}$ organic wastes, the best 
consortium was selected to be employed in the upscaling of the organic waste degradation.

\section{Scaling up of degradation study using the best consortium}

On the basis of results obtained from laboratory trials, the best consortium was selected for further scaling up of the degradation study using $30 \mathrm{~kg}$ wastes. The degradation study was done using the composting process, because composting incurs lower cost and has lesser negative impact on the environment (Lim et al. 2016). In addition, composting of biodegradable solid wastes is deemed useful for its utilizable end product as nutrient-rich organic fertilizers or for land application (Wu et al. 2014). In this study, organic wastes, collected from different canteens of North Bengal University was inoculated individually with overnight grown the best consortium $(5 \% \mathrm{v} / \mathrm{v})$. The consortium was mixed evenly and kept under normal environmental conditions for a month to observe the degradation. The heaps were mixed periodically to maintain aeration. A second set of uninoculated organic wastes was kept under similar experimental conditions that served as the control. The sample was withdrawn periodically at a constant interval of 7 days till 28 days, and waste degradation was measured on the basis of the following parameters: volume reduction, density increase, mass reduction, temperature change and moisture content of the compost following the protocol explained in the previous section.

\section{Chemical analysis of waste}

The $30 \mathrm{~kg}$ organic waste inoculated with the best consortium was subjected to compost analysis after 30 days of degradation study. This included tests for the quantitative analysis of factors: $\mathrm{pH}$, electrical conductivity (E.C.), organic matter, $\mathrm{C}: \mathrm{N}$ ratio, phosphorus, potassium and sulphur. This test was performed to observe the ability of the degraded organic waste to be used as manure to increase the fertility of soil.

\section{Results and discussion}

\section{Determination of moisture content of the soil sample}

The soil sample collected from the waste dumping site of Matigarahat was dried at $110{ }^{\circ} \mathrm{C}$ and weighed until a constant weight was attained. The moisture content of the sample was calculated using the formula by AWPA and it was found to be $52 \%$. High bacterial density is found at high moisture content and optimal activity of aerobic bacteria lies at the moisture content range of $50-75 \%$. Aerobic soil commonly consists of bacteria Pseudomonas sp., Bacillus sp. and Clostridium sp., along with a higher population of Actinomycetes (Alexander 1977).

\section{Chemical analysis of the soil sample}

The chemical characteristics of the soil sample were determined with the following parameters: $\mathrm{pH}$, organic carbon $(\%)$, nitrogen $(\%)$, potassium $(\mathrm{ppm})$, phosphorus (ppm), sulphur (ppm), organic matter (\%) and electrical conductivity (EC). The results are summarized in Table 1 . Soil $\mathrm{pH}$ is hydrogen ion activity measurement and depends on relative amounts of absorbed metallic ions and hydrogen. The $\mathrm{pH}$ was determined with a soil to water ratio of $1: 2.5$. The $\mathrm{pH}$ of the soil sample was 5.49 , which is slightly acidic. The reason for this can be attributed to the very high levels of available sulphur (30 ppm), resulting from organic matter degradation as the soil was collected from the organic waste-rich dumping site (Bezdicek et al. 2002).

Electrical conductivity is the measurement of the ability to transport electric charge. The EC of soil depends on salts and sodium content level. Uncontrolled discharge of wastes results in the significant increase of EC that can be toxic to plants, preventing their ability to obtain water from soil. The EC value of soil less than $0.5 \mathrm{~m} \mathrm{mho} / \mathrm{cm}$ is considered safe for plant growth. The result showed that the EC of the soil sample was $0.12 \mathrm{~m} \mathrm{mho/cm}$, which was considered safe for plant growth.

A proper $\mathrm{C}: \mathrm{N}$ ratio must be present in soil for organisms to grow. Excess of carbon in soil means a surplus presence of energy, and microbial cells will draw larger amount of nitrogen to make use of available carbon. This is known as 'robbing' the soil of nitrogen and it delays the availability of nitrogen as fertilizer in soil (Meuser 2010). A C:N ratio of less than 20 is good for the growth of organisms the soil of nitrogen. The C:N ratio of the soil sample was 12.5, which is considered good for microbial growth. However, Rawat et al. (2008) found the C:N ratio of Indian dumpsites to vary between 11 and 30, which is in agreement with our result.

The level of nitrogen was $0.11 \%$, which was fairly low. Meuser et al. (2011) found the nitrogen content of waste dumping site to range between 0.34 and $0.54 \%$. However, higher levels of potassium and phosphorus were observed due to the high solubility of $\mathrm{K}$ and $\mathrm{P}$ in solid wastes that get readily leached to soil. The sources of these minerals are considered to be the organic materials in wastes.

The sulphur content of the soil sample was reported to be $30 \mathrm{ppm}$. Pillai et al. (2014) also reported the presence of $25 \mathrm{ppm}$ sulphur content in the soil at the dumping site. This level is considered very high and is good for the growth of annual crops such as cabbage. High levels of sulphur 
Table 1 Chemical analysis of soil

\begin{tabular}{llllllll}
\hline $\mathrm{pH}$ & Org carbon $(\%)$ & E.C $(\mathrm{m} \mathrm{mho} / \mathrm{cm})$ & $\mathrm{N}(\%)$ & $\mathrm{K}_{2} \mathrm{O}(\mathrm{ppm})$ & $\mathrm{P}_{2} \mathrm{O}_{5}(\mathrm{ppm})$ & Sulphur $(\mathrm{ppm})$ & Org. matter $(\%)$ \\
\hline 5.49 & 1.38 & 0.12 & 0.11 & 68.5 & 15 & 30 & 2.37 \\
\hline
\end{tabular}

indicate the presence of decaying organic matter in the soil and results in low soil $\mathrm{pH}$.

\section{Isolation of bacteria from soil sample}

19 different bacterial colonies were isolated from the soil sample by the serial dilution method after $24 \mathrm{~h}$ incubation at $37{ }^{\circ} \mathrm{C}$. The bacterial isolates were screened according to colony morphology (shape, margin, elevation texture) and pigmentation. The results are summarized in Table 2. A similar method was used by for the successful isolation of organisms from municipal solid waste. The organisms were further utilized in consortia for fast and effective degradation of organic waste (Saha and Santra 2014).

\section{Screening of bacteria for the production of extracellular enzymes}

The isolated bacteria were screened for the production of five extracellular enzymes (amylase, cellulase, protease, lipase and pectinase) that are required for the effective degradation of organic solid wastes. The organisms were streaked on plates with the respective screening media and the zone of hydrolysis was observed after $24 \mathrm{~h}$ incubation. The gram characteristics of the isolates were also determined.

10 different bacterial cultures were screened out of the 19 bacterial isolates on the basis of extracellular enzyme production and gram characteristics (Table 3). Sarkar et al. (2011) reported 35 bacterial isolates out of 80 isolates that showed similar enzyme production. The soil of dumping sites is subjected to high concentration of organic material, which consists of various kinds of substrates for the indigenous organisms in the soil. Micro-organisms residing in soil with heightened supply of substrates develop mechanisms to secrete increased concentration of extracellular enzymes to utilize the available substrate (Raju and Divakar 2013).

\section{Proposed composition of consortium}

To prepare a successful microbial consortium, the bacterial cultures must be compatible with each other to concomitantly produce all these enzymes required for the degradation of organic wastes. Four different microbial consortia were prepared by permutation and combination (Table 4),
Table 2 Morphological characterization of the isolated strains from waste dumping site

\begin{tabular}{llllll}
\hline Bacterial colony & Shape & Margin & Elevation & Pigmentation & Texture \\
\hline $\mathrm{W}_{1} \mathrm{~A}$ & Filamentous & Filamentous & Flat & White & Dry \\
$\mathrm{W}_{1} \mathrm{~B}$ & Circular & Entire & Convex & Pale & Mucoid \\
$\mathrm{W}_{1} \mathrm{C}$ & Circular & Entire & Flat & Pink & Dry \\
$\mathrm{W}_{1} \mathrm{D}$ & Circular & Entire & Convex & White & Mucoid \\
$\mathrm{W}_{1} \mathrm{E}$ & Irregular & Entire & Raised & Pale & Dry \\
$\mathrm{W}_{1} \mathrm{~F}$ & Circular & Entire & Raised & Orange & Glossy \\
$\mathrm{W}_{1} \mathrm{G}$ & Circular & Entire & Raised & Yellow & Glossy \\
$\mathrm{W}_{1} \mathrm{H}$ & Circular & Irregular & Convex & Pale & Glossy \\
$\mathrm{W}_{1} \mathrm{I}$ & Rhizoid & Lobate & Raised & White & Mucoid \\
$\mathrm{W}_{1} \mathrm{~J}$ & Irregular & Rhizoid & Flat & White & Rough \\
$\mathrm{W}_{1} \mathrm{~K}$ & Irregular & Lobed & Flat & White & Rough \\
$\mathrm{W}_{1} \mathrm{P}$ & Circular & Entire & Convex & Pale & Glossy \\
$\mathrm{W}_{1} \mathrm{Q}$ & Punctiform & Entire & Convex & Yellow & Glossy \\
$\mathrm{W}_{1} \mathrm{R}$ & Circular & Entire & Convex & Orange & Glossy \\
$\mathrm{W}_{1} \mathrm{~S}$ & Punctiform & Entire & Convex & White & Mucoid \\
$\mathrm{W}_{1} \mathrm{~T}$ & Circular & Entire & Convex & Oily yellow & Mucoid \\
$\mathrm{W}_{1} \mathrm{U}$ & Circular & Entire & Convex & White & Glossy \\
$\mathrm{W}_{1} \mathrm{~V}$ & Irregular & Undulate & Raised & Opaque & Glossy \\
$\mathrm{W}_{1} \mathrm{~W}$ & Punctiform & Entire & Convex & Orange & Glossy \\
\hline & & & &
\end{tabular}


Table 3 Screening of the isolates on the basis of enzyme production and cell morphology

\begin{tabular}{llllllll}
\hline Bacteria & Amylase & CMCase & Protease & Lipase & Pectinase & Gram nature & Morphology \\
\hline $\mathrm{W}_{1} \mathrm{~A}$ & + & - & - & ++ & +++ & Positive & Rods \\
$\mathrm{W}_{1} \mathrm{~B}$ & - & - & ++ & +++ & +++ & Positive & Cocci \\
$\mathrm{W}_{1} \mathrm{C}$ & +++ & - & + & +++ & +++ & Positive & Rods \\
$\mathrm{W}_{1} \mathrm{D}$ & - & - & - & +++ & +++ & Negative & Cocci \\
$\mathrm{W}_{1} \mathrm{E}$ & ++ & - & ++ & +++ & +++ & Positive & Rods \\
$\mathrm{W}_{1} \mathrm{~F}$ & - & - & - & ++ & +++ & Positive & Rods \\
$\mathrm{W}_{1} \mathrm{G}$ & - & - & - & ++ & +++ & Positive & Cocci \\
$\mathrm{W}_{1} \mathrm{H}$ & - & - & - & ++ & +++ & Positive & Cocci \\
$\mathrm{W}_{1} \mathrm{I}$ & - & ++ & +++ & +++ & - & Negative & Rods \\
$\mathrm{W}_{1} \mathrm{~J}$ & - & - & - & +++ & +++ & Negative & Cocci \\
$\mathrm{W}_{1} \mathrm{~K}$ & - & +++ & - & ++ & - & Positive & Rods \\
$\mathrm{W}_{1} \mathrm{P}$ & - & - & - & ++ & - & Negative & Cocci \\
$\mathrm{W}_{1} \mathrm{Q}$ & + & - & - & ++ & +++ & Negative & Cocci \\
$\mathrm{W}_{1} \mathrm{R}$ & - & - & ++ & ++ & +++ & Positive & Cocci \\
$\mathrm{W}_{1} \mathrm{~S}$ & - & - & - & ++ & - & Positive & Rods \\
$\mathrm{W}_{1} \mathrm{~T}$ & + & - & ++ & + & +++ & Negative & Cocci \\
$\mathrm{W}_{1} \mathrm{U}$ & - & - & + & +++ & - & Negative & Cocci \\
$\mathrm{W}_{1} \mathrm{~V}$ & +++ & - & + & +++ & +++ & Negative & Rods \\
$\mathrm{W}_{1} \mathrm{~W}$ & +++ & - & + & ++ & - & Negative & Cocci \\
\hline
\end{tabular}

- no enzyme production, + low, ++ moderate, +++ high enzyme production
Table 4 Proposed composition of the consortium

\begin{tabular}{ll}
\hline Combination & Composition \\
\hline 1 & $\mathrm{~W}_{1} \mathrm{C}, \mathrm{W}_{1} \mathrm{I}, \mathrm{W}_{1} \mathrm{E}, \mathrm{W}_{1} \mathrm{~K}$ \\
2 & $\mathrm{~W}_{1} \mathrm{R}, \mathrm{W}_{1} \mathrm{~T}, \mathrm{~W}_{1} \mathrm{~V}, \mathrm{~W}_{1} \mathrm{~K}$. \\
3 & $\mathrm{~W}_{1} \mathrm{~V}, \mathrm{~W}_{1} \mathrm{~K}, \mathrm{~W}_{1} \mathrm{~B}, \mathrm{~W}_{1} \mathrm{~W}$ \\
4 & $\mathrm{~W} 1 \mathrm{~B}, \mathrm{~W}_{1} \mathrm{E}, \mathrm{W}_{1} \mathrm{~K}, \mathrm{~W}_{1} \mathrm{Q}$ \\
\hline
\end{tabular}

keeping in mind their concomitant enzyme production and gram character. The compatibility of the bacterial strains within the consortia was checked by antagonism assay.

\section{Antagonism assay}

A cross streaking method was used to test antagonism among the bacterial strains within the proposed consortia. Plates were observed after incubation for zone of inhibition, which would indicate the presence of antagonism between organisms. Among the four combinations, two combinations of organisms (consortium 1 and 2) showed no antagonism among each other as shown in Fig. 1a, b.

Positive antagonism was observed in the case of combinations 3 and 4 . The zone of inhibition of growth caused by antagonism is illustrated in Fig. 1c. Organisms $\mathrm{W}_{1} \mathrm{~B}$ inhibited the growth of $\mathrm{W}_{1} \mathrm{Q}, \mathrm{W}_{1} \mathrm{Q}$ inhibited the growth of $\mathrm{W}_{1} \mathrm{E}$, and $\mathrm{W}_{1} \mathrm{~K}$ and $\mathrm{W}_{1} \mathrm{~W}$ inhibited the growth of $\mathrm{W}_{1} \mathrm{~B}$. Therefore, they were not further considered for consortium preparation.
Preparation of a successful consortium requires the micro-organisms in the consortium to grow in the presence of each other without hampering the activities of other native micro-organisms. Antagonistic relations between micro-organisms of a consortium lead to instability of the consortium and the expected functioning of the consortium is not obtained. The result of the antagonism assay between organisms of individual combination is presented in Table 5.

Micro-organisms grow in various associations with other organisms, one of them being an antagonistic relation. Antagonist micro-organisms can employ various mechanisms to inhibit the growth of other microbes, including production of toxins, antibiotics and siderophores (Hibbing et al. 2010). Van Hamme et al. (2003) showed the presence of antagonistic relations between microbes in a population of mixed community.

Combinations 1 and 2 lacked antagonism and thus were selected for further consortium preparation. Consortia were prepared by inoculating $150 \mu \mathrm{l}$ each of four overnightgrown cultures in $20 \mathrm{ml}$ sterile nutrient broth for each consortium.

\section{Concomitant enzyme production by the consortium}

Czapek Dox mineral salt broth was selected for concomitant enzyme production, because it is a defined medium where all the constituents are known. This medium was 
Fig. 1 Determination of antagonism among the bacterial strains within the proposed consortia. Antagonism assay for combination 1 (a), combination 2 (b), and combinations 3 and 4 (c) (a)

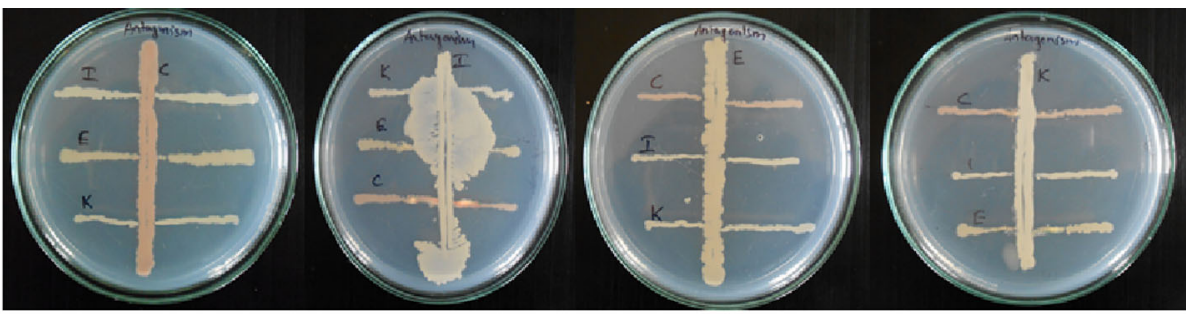

(b)

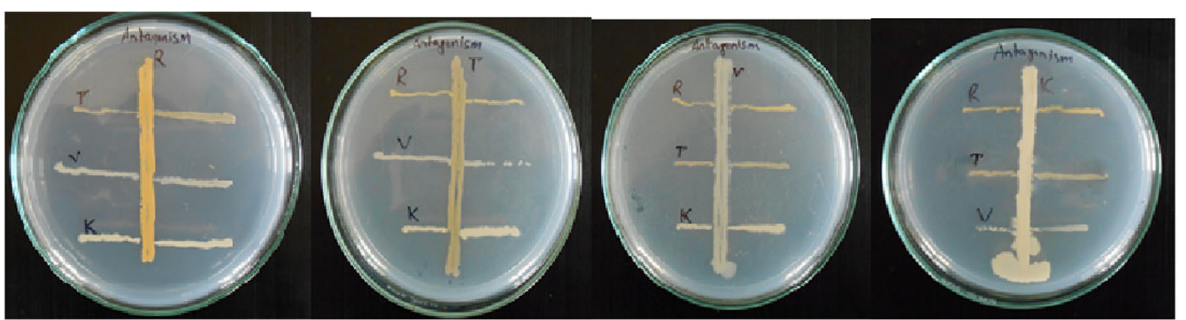

(c)

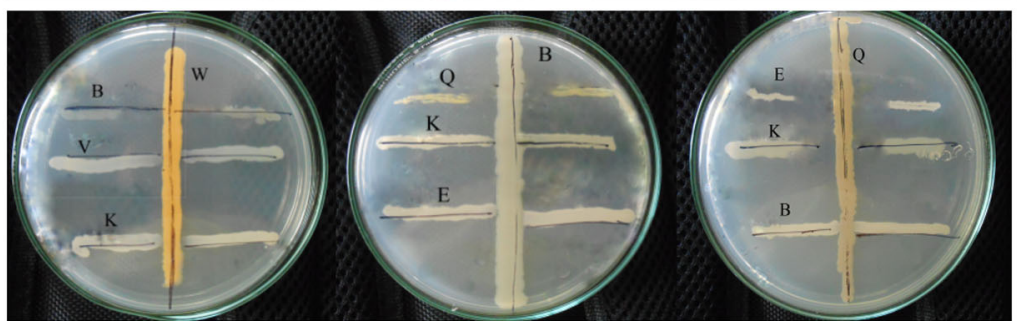

supplemented with five substrates (CMC, starch, skimmed milk, pectin and tributyrin oil) and different extracellular enzyme productions were assayed after every $24 \mathrm{~h}$ interval till 7 days.

Consortium 2 showed the highest amylase activity on day 2 (Fig. 2a), followed by a gradual decline. A delay in cellulose activity was observed in both the consortia. The highest cellulase activity was noted on day 5 in consortium 1 , whereas in consortium 2 it was highest on day 4. Consortium 1 had the highest cellulase activity (Fig. 2b). Consortium 1 showed greater protease activity than consortia 2, and the highest activity was observed on day 4 (Fig. 2c). Pectinase activity was significantly high for both the consortia from day 1 and kept increasing till day 4; consortia 2 showed slightly higher activity than consortium 1 (Fig. 2d).

The results of the lipase assay were different from those of the rest of the enzymes. No activity was observed for both the consortia on day 1. Enzyme activity was exhibited on day 2 only by consortium 2 . Significant increase in lipase activity was observed in both the consortia after $72 \mathrm{~h}$ incubation with a constant increase till day 7. Consortium 2 showed higher activity than consortium 1 (Fig. 2e).

Among the two consortia, consortium 2 showed better concomitant enzyme production compared to consortium 1 . Both the consortia were selected for laboratory trial with $5 \mathrm{~kg}$ organic waste. Similarly, Gopinath et al. (2014) constructed five different microbial consortia and the compatibility of the consortia to degrade organic waste was checked by enzyme assays of four substrates (starch, cellulose, casein and tributyrin). Sarkar et al. (2011) also reported three consortia out of 11 different microbial consortia that were concomitant producers of all three enzymes.

\section{Determination of organic waste degradation $(5 \mathrm{~kg}$ laboratory trials)}

Consortia 1 and 2 were subjected to $5 \mathrm{~kg}$ of organic waste degradation for 28 days. The degradation capabilities were tested on the basis of various parameters at a constant interval of 7 days till 28 days.

Determination of physical changes in waste (volume, density and mass)

A rapid decrease in waste volume was observed in both the consortia as well as in the control after the first week. However, decrease in volume for consortium 2 was greater than that in consortium 1. After 28 days trial, $85 \%$ volume of the waste decreased in case of consortium 2 and $72 \%$ in consortium 1 (Fig. 3a), whereas only $55 \%$ volume reduction was observed in the control. Elango et al. (2009) observed degradation of MSW by thermophilic composting with $78 \%$ volume reduction of raw MSW in 40 days. The resulting compost provided good humus to build up soil characteristics and some basic plant nutrient. 
Table 5 Antagonism assay for the proposed microbial combination

\begin{tabular}{lllll}
\hline Combination 1 & & & & \\
\hline Organisms & $\mathrm{W}_{1} \mathrm{C}$ & $\mathrm{W}_{1} \mathrm{I}$ & $\mathrm{W}_{1} \mathrm{E}$ & $\mathrm{W}_{1} \mathrm{~K}$ \\
\hline $\mathrm{W}_{1} \mathrm{C}$ & $\mathrm{X}$ & - & - & - \\
$\mathrm{W}_{1} \mathrm{I}$ & - & $\mathrm{X}$ & - & - \\
$\mathrm{W}_{1} \mathrm{E}$ & - & - & $\mathrm{X}$ & - \\
$\mathrm{W}_{1} \mathrm{~K}$ & - & - & - & $\mathrm{X}$ \\
\hline
\end{tabular}

Combination 2

\begin{tabular}{lllll}
\hline Organisms & $\mathrm{W}_{1} \mathrm{R}$ & $\mathrm{W}_{1} \mathrm{~T}$ & $\mathrm{~W}_{1} \mathrm{~V}$ & $\mathrm{~W}_{1} \mathrm{~K}$ \\
\hline $\mathrm{W}_{1} \mathrm{R}$ & $\mathrm{X}$ & - & - & - \\
$\mathrm{W}_{1} \mathrm{~T}$ & - & $\mathrm{X}$ & - & - \\
$\mathrm{W}_{1} \mathrm{~V}$ & - & - & $\mathrm{X}$ & - \\
$\mathrm{W}_{1} \mathrm{~K}$ & - & - & - & $\mathrm{X}$ \\
\hline
\end{tabular}

Combination 3

\begin{tabular}{lllll}
\hline Organisms & $\mathrm{W}_{1} \mathrm{~V}$ & $\mathrm{~W}_{1} \mathrm{~K}$ & $\mathrm{~W}_{1} \mathrm{~B}$ & $\mathrm{~W}_{1} \mathrm{~W}$ \\
\hline $\mathrm{W}_{1} \mathrm{~V}$ & $\mathrm{X}$ & - & - & - \\
$\mathrm{W}_{1} \mathrm{~K}$ & - & $\mathrm{X}$ & - & - \\
$\mathrm{W}_{1} \mathrm{~B}$ & - & - & $\mathrm{X}$ & - \\
$\mathrm{W}_{1} \mathrm{~W}$ & - & - & + & $\mathrm{X}$ \\
\hline
\end{tabular}

Combination 4

\begin{tabular}{lllll}
\hline Organisms & $\mathrm{W}_{1} \mathrm{~B}$ & $\mathrm{~W}_{1} \mathrm{E}$ & $\mathrm{W}_{1} \mathrm{~K}$ & $\mathrm{~W}_{1} \mathrm{Q}$ \\
\hline $\mathrm{W}_{1} \mathrm{~B}$ & $\mathrm{X}$ & - & - & + \\
$\mathrm{W}_{1} \mathrm{E}$ & - & $\mathrm{X}$ & - & - \\
$\mathrm{W}_{1} \mathrm{~K}$ & - & - & $\mathrm{X}$ & - \\
$\mathrm{W}_{1} \mathrm{Q}$ & - & + & + & $\mathrm{X}$ \\
\hline
\end{tabular}

$X$ identical organism, - no antagonism, + antagonism present

Density and volume are inversely related and a rapid decrease in volume indicates increasing density. As expected, the density of $5 \mathrm{~kg}$ waste increased in consortium 2 , as it exhibited $85 \%$ decrease in volume of waste. Increase in density is important during composting, as it indicates particle size decrease due to waste degradation. Compost supplemented with consortium 2 showed significant density increase in comparison to consortium 1 and the control (Fig. 3b). Tom et al. (2016) reported a 50\% density enhancement of bio-treated MSW resulting in compaction of the compost.

Mass reduction is a primary objective of waste treatment processes. Organic matter is utilized by degrading organisms and incorporated into cells and is also released as gas which causes a reduction in waste mass (Tom et al. 2016). Significant reduction in mass was observed for waste supplemented with consortium 2 in comparison to other composts, indicating better degradation amounting in reduction up to $70 \%$ of the initial mass (Fig. 3c). Higgins et al. (2006) also reported similar mass reduction of $70 \%$ during composting of municipal solid waste and emphasized the eligibility of the compost to be used as a fertilizer in soil for plant growth.

\section{Determination of moisture content in waste}

Water is a critical factor during composting. Compost moisture content above $80 \%$ leads to decrease of oxygen diffusion, resulting in the composting process to slow down and become anaerobic. A moisture content of $40-60 \%$ should be maintained during the composting process for proper microbial process. The moisture content reduction was uniform for the first 7 days for both test consortia and control composts, indicating moisture reduction due to drying and evaporation (Fig. 3d). 40\% moisture content was found after 28 days of degradation study in consortium 2 , whereas the moisture content was 45 and $65 \%$ in case of consortium 1 and control, respectively. Increase in moisture reduction in consortium 2 was more due to temperature rise, resulting from increased microbial degradation activities. Gautam et al. (2010) performed composting of MSW of Jabalpur City and observed a final moisture content of $36 \%$ in the final compost. This moisture content of compost is within the quality parameters set by international standards.

\section{Change in temperature}

Temperature changes of the three levels of the waste were observed after every 7 days interval. The temperature of the compost pile rose quickly and reached a peak at day 14 (Table 6), for all the test and control composts. Compost supplemented with consortium 2 attained the highest temperature among the test composts at all the three levels, and the highest temperature was observed in the centre layer $\left(48{ }^{\circ} \mathrm{C}\right)$. Rise of temperature is associated with vigorous microbial activity and rapid organic matter degradation. Increase in temperature leads to degradation of waste by thermophilic organisms that supplement mesophilic degradation (Tom et al. 2016).

Temperature increase leads to reduction in pathogenic organism population, though turning of the compost pile at regular interval was employed to prevent increase of temperature to such extents that would kill the degrading organisms and stop the degradation process. This result supports the mass and volume reduction results, where consortium 2 demonstrated higher reduction in mass and volume than compost supplemented with consortium 1 . Singh and Sharma (2003) observed the highest temperature $\left(58{ }^{\circ} \mathrm{C}\right)$ at the bottom of the compost pile with maximum temperature increase from the 14 th to the 21 st day. 
Fig. 2 Concomitant enzyme production by consortium 1 (black bar) and consortium 2 cellulase activity (b), protease activity $(\mathbf{c})$, pectinase activity (d) and lipase activity (e) (grey bar) amylase activity (a),
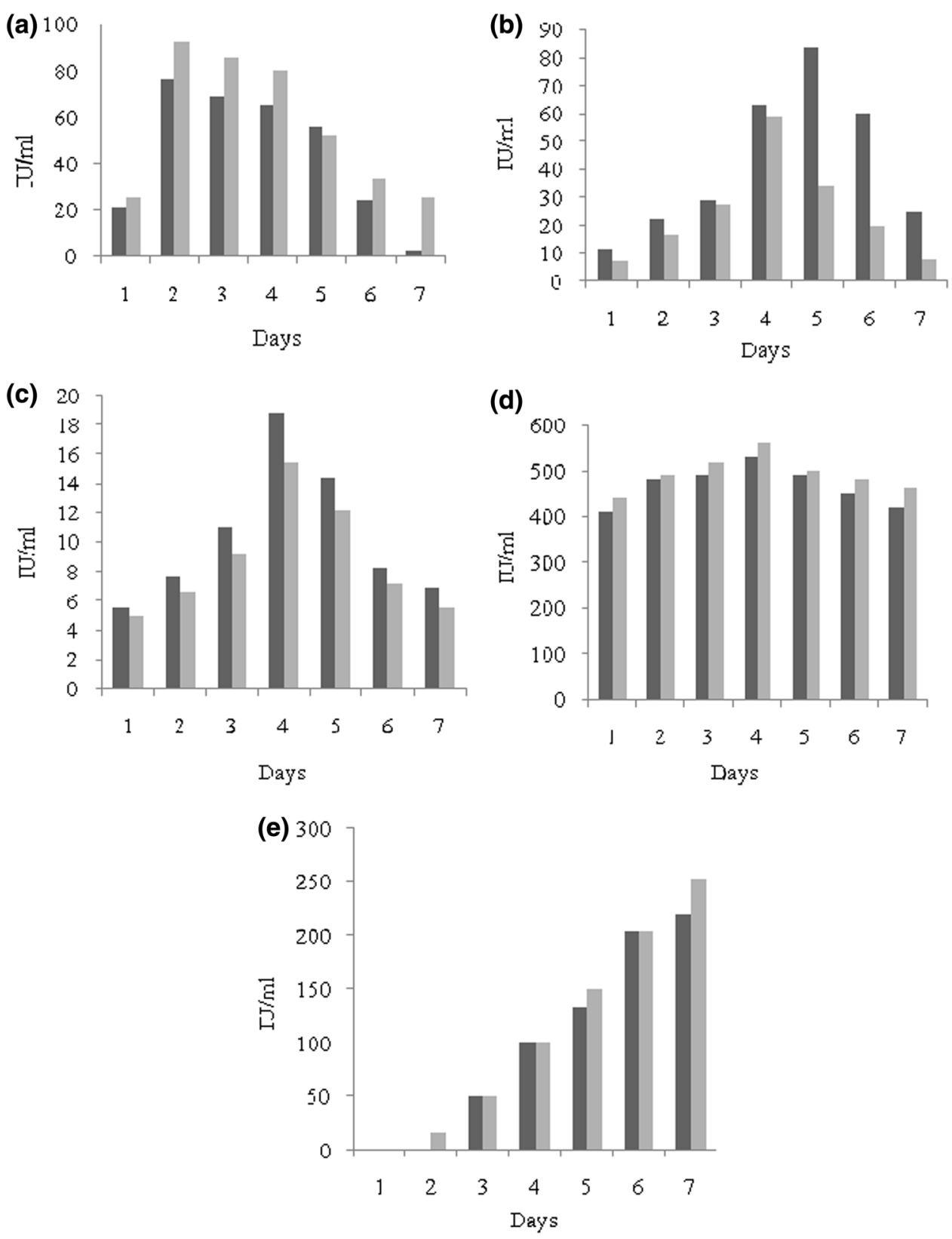

\section{Changes in colour and odour of the wastes}

Wastes inoculated with consortia and control varied in colour, texture and other characteristics after 28 days. Waste inoculated with consortium 2 was dark (Fig. 4), had a grainy texture and had very low smell (Visilind and Spinosa 2001). It lacked the presence of crustaceans. Consortium 1-inoculated waste had a slight slimy texture and the presence of a small population of crustaceans, whereas the control had a sharp rotten stench. This might be a result of domination of anaerobic bacteria in the control waste which produce hydrogen sulphide and other sources of offensive odour such as cadaverine, in addition to organic acids and amines (Higgins et al. 2006).

In addition to the smell, the control consortium was teeming with small crustaceans including millipedes which are essentially harmless to the composting process; instead crustaceans break down the organic waste to help in further degradation (Shamaini and Fauzia 2014). But the presence of these organisms indicate that the temperature of the compost is not high enough as required for the degradation of the waste by thermophilic micro-organisms and thus the process of degradation of the control compost was slower than composts inoculated with the consortium. 
Fig. 3 Determination of various parameters of $5 \mathrm{~kg}$ organic waste degradation laboratory trials (consortium 1 , consortium 2, control).

a Volume reduction, $\mathbf{b}$ waste density, $\mathbf{c}$ mass reduction and d moisture content reduction
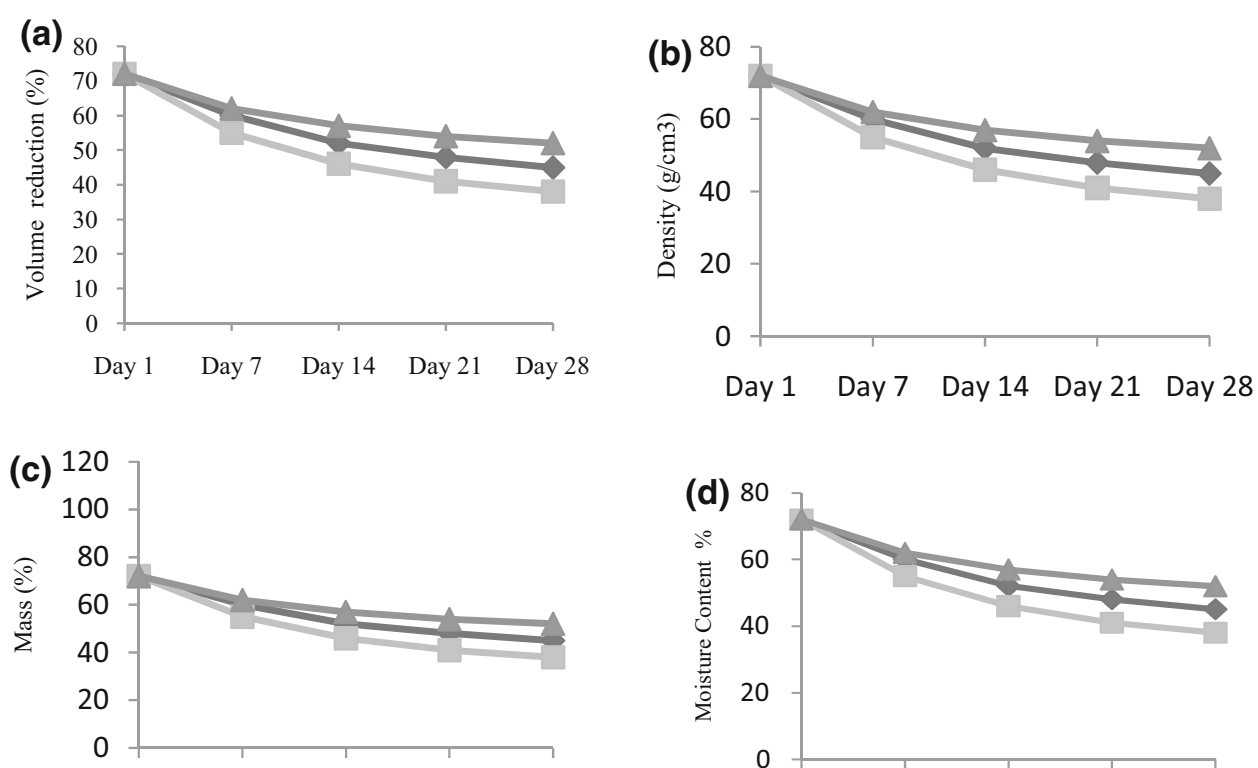

Day 1 Day 7 Day 14 Day 21 Day 28

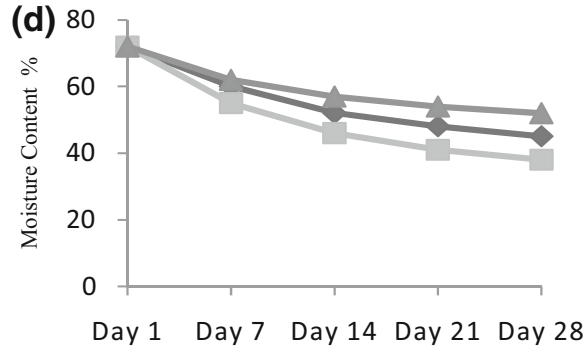

Table 6 Determination of temperature changes in the $5 \mathrm{~kg}$ compost

\begin{tabular}{lllll}
\hline Day & Level & \multicolumn{2}{l}{ Temperature $\left({ }^{\circ} \mathrm{C}\right)$} \\
\cline { 3 - 5 } & & Control & Con 1 & Con 2 \\
\hline 1 & Surface & 31 & 31 & 31 \\
& Centre & 37 & 39 & 37 \\
7 & Bottom & 36 & 36 & 35 \\
& Surface & 34 & 37 & 35 \\
& Centre & 40 & 45 & 44 \\
\multirow{4}{*}{21} & Bottom & 38 & 41 & 40 \\
& Surface & 38 & 41 & 43 \\
& Centre & 40 & 46 & 48 \\
& Bottom & 39 & 41 & 43 \\
& Surface & 37 & 39 & 42 \\
& Centre & 40 & 42 & 45 \\
& Bottom & 38 & 39 & 42 \\
& Surface & 35 & 38 & 40 \\
& Centre & 39 & 40 & 43 \\
& Bottom & 37 & 38 & 42 \\
\hline
\end{tabular}

\section{Scaling up of the degradation study using the best consortium}

Among the two consortia used for laboratory trials with $5 \mathrm{~kg}$ waste, consortium 2 showed better degradation capabilities and thus was selected for further scaling up of the degradation study using $30 \mathrm{~kg}$ organic waste. Degradation and compost maturation with $30 \mathrm{~kg}$ waste were tested on the basis of the same parameters that were

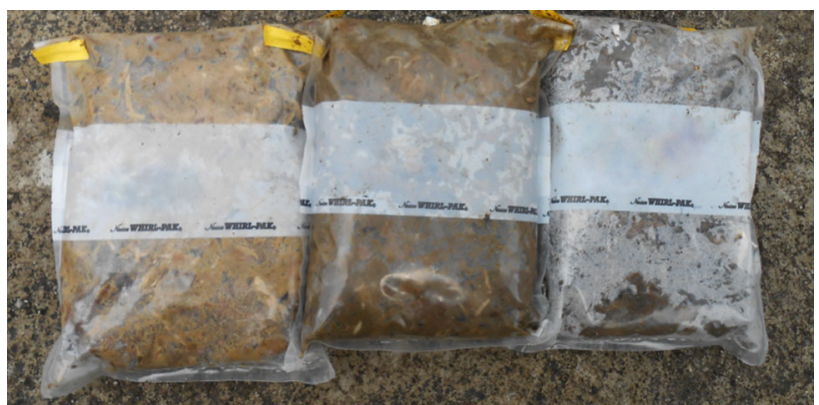

Fig. 4 Determination of colour and texture changes in $5 \mathrm{~kg}$ waste after 28 days of degradation study

checked during $5 \mathrm{~kg}$ of laboratory trials for 30 days at an interval of 7 days. Reduction of volume in $30 \mathrm{~kg}$ waste inoculated with consortium 2 followed a similar pattern, as was observed during $5 \mathrm{~kg}$ trials. During the 30 days trial, the volume of the inoculated waste was decreased by $82 \%$ which was similar to $85 \%$ volume reduction of $5 \mathrm{~kg}$ waste (Fig. 5a).

A maximum density value of $0.85 \mathrm{~g} / \mathrm{cm}^{3}$ was observed for the $30 \mathrm{~kg}$ waste, which was in accordance to the density value $0.90 \mathrm{~g} / \mathrm{cm}^{3}$ observed for $5 \mathrm{~kg}$ wastes inoculated with consortium 2 (Fig. 5b). The mass reduction observed for $30 \mathrm{~kg}$ waste was $65 \%$, which correlated with $68.75 \%$ mass reduction observed for $5 \mathrm{~kg}$ waste. This difference is insignificant and indicative of the ability of consortium 2 to sustain its waste degradative capability of larger quantity of wastes (Fig. 5c). The final moisture content of $30 \mathrm{~kg}$ waste was $42 \%$ as compared to $40 \%$ observed during $5 \mathrm{~kg}$ trials. The maximum reduction in moisture content for $30 \mathrm{~kg}$ waste was observed during the 28th day as compared to 
Fig. 5 Comparison of various parameters of 5 and $30 \mathrm{~kg}$ organic waste degradation by consortium 2. a Volume reduction, $\mathbf{b}$ waste density, $\mathbf{c}$ mass reduction and $\mathbf{d}$ moisture content reduction
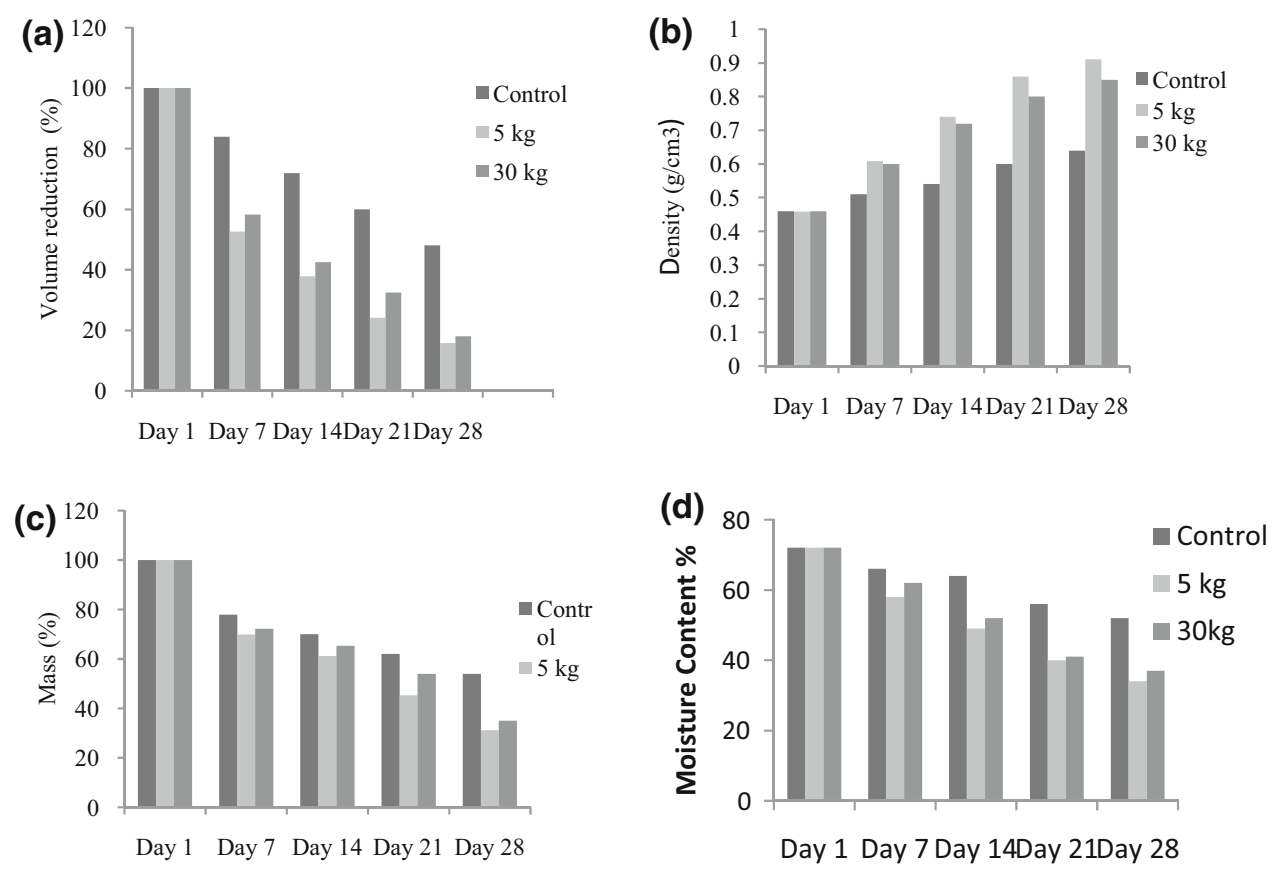

Table 7 Comparison of temperature difference in the $5 \mathrm{~kg}$ and $30 \mathrm{~kg}$ waste

\begin{tabular}{lllll}
\hline Day & Level & \multicolumn{3}{l}{ Temperature $\left({ }^{\circ} \mathrm{C}\right)$} \\
\cline { 3 - 5 } & & Control & $5 \mathrm{~kg}$ & $30 \mathrm{~kg}$ \\
\hline 1 & Surface & 35 & 31 & 35 \\
& Centre & 38 & 37 & 39 \\
7 & Bottom & 36 & 35 & 35 \\
& Surface & 40 & 35 & 42 \\
& Centre & 43 & 44 & 45 \\
\multirow{4}{*}{21} & Bottom & 39 & 40 & 43 \\
& Surface & 42 & 43 & 46 \\
& Centre & 44 & 48 & 49 \\
& Bottom & 33 & 43 & 47 \\
& Surface & 44 & 42 & 51 \\
& Centre & 48 & 45 & 54 \\
& Bottom & 45 & 42 & 50 \\
& Surface & 40 & 40 & 49 \\
& Centre & 44 & 43 & 56 \\
& Bottom & 43 & 42 & 50 \\
\hline
\end{tabular}

maximum moisture reduction of $5 \mathrm{~kg}$ waste during the first 2 weeks (Fig. 5d).

Increase in temperature of the $30 \mathrm{~kg}$ waste was higher than the temperature rise for $5 \mathrm{~kg}$ wastes. A maximum value of $54{ }^{\circ} \mathrm{C}$ was observed in $30 \mathrm{~kg}$ waste, while a maximum temperature of $45^{\circ} \mathrm{C}$ was observed in $5 \mathrm{~kg}$ waste at the 21 st day (Table 7 ).

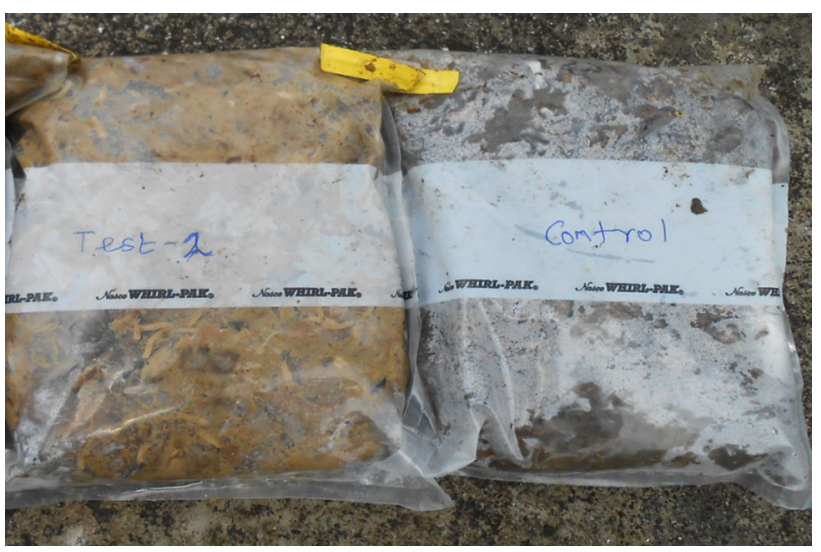

Fig. 6 Determination of colour and texture changes in $30 \mathrm{~kg}$ waste after 30 days of degradation study

The colour and odour of the $30 \mathrm{~kg}$ waste after 30 days were similar to the results obtained for the $5 \mathrm{~kg}$ waste. The waste had developed a dark colour, had a grainy texture and lacked crustacean population in comparison to the control waste; it also lacked the foul smell observed in control waste (Fig. 6).

\section{Chemical analysis of the compost}

The waste inoculated with consortium 2 was subjected to further compost analysis after the successful degradation of $30 \mathrm{~kg}$ wastes. This included tests for the quantitative analysis of the factors: $\mathrm{pH}$, electrical conductivity (E.C), organic matter, $\mathrm{C}: \mathrm{N}$ ratio, phosphorus, potassium, sulphur. The results of compost analysis are tabulated in Table 8 . 
Table 8 Chemical analysis of the final compost

\begin{tabular}{llllllll}
\hline Sample & $\mathrm{pH}$ & $\mathrm{E} . \mathrm{C}(\mathrm{m} \mathrm{mho} / \mathrm{cm})$ & Org. matter $(\%)$ & $\mathrm{C}: \mathrm{N}$ & $\mathrm{K}_{2} \mathrm{O}(\%)$ & $\mathrm{P}_{2} \mathrm{O}_{5}(\%)$ & Sulphur (\%) \\
\hline Fresh waste & 6.38 & 1.90 & 33.35 & $32: 1$ & 0.39 & 0.32 & 0.08 \\
Control & 5.91 & 1.96 & 21.17 & $29: 1$ & 0.48 & 0.41 & 0.08 \\
Test compost & 6.71 & 2.11 & 18.06 & $22: 1$ & 0.55 & 0.50 & 0.10 \\
\hline
\end{tabular}

The $\mathrm{pH}$ of the control compost (5.91) was lower than that of the test compost (6.71), indicating the dominance of anaerobic organisms instead of thermophilic degraders in the control. This resulted in slow and less degradation of waste in the control compost compared to the test.

Reports also suggest that production of organic acids and other anaerobic degradation products lead to the generation of foul odour and a decrease in $\mathrm{pH}$ (Tejada and Gonzalez 2007). The $\mathrm{pH}$ of the test compost was 6.7, an ideal property of the compost to be used to increase soil fertility.

Compost EC typically ranges from values between 1 and $10 \mathrm{~m} \mathrm{mho/cm} \mathrm{(Tambone} \mathrm{et} \mathrm{al.} \mathrm{2013).} \mathrm{The} \mathrm{EC} \mathrm{of} \mathrm{the} \mathrm{test}$ compost was $2.11 \mathrm{~m}$ mhos/cm. Reports suggested that the application of E. eugeniae increased the EC value and permitted a significant increase in salts such as $\mathrm{Ca}$ (42.3-91.6\%), K (93.8-235\%), Mg (25.4-84.6\%) and $\mathrm{P}$ (37.1-129\%) due to degradation of organic matter, which is important in delivering essential minerals to the plant (Lim et al. 2011). Janakrinam and Sridevi (2010) reported an increase of EC content from 7.39 to $10.77 \mathrm{~m} \mathrm{mho} / \mathrm{cm}$ during MSW composting.

The organic matter content of the test compost was $18.06 \%$ lesser than that of the control compost $(21.17 \%)$ after 28 days. Organic matter content decreases with composting as the degrading organisms utilize the organic carbon for energy generation and biosynthesis. This reduction of organic matter in the test compost explains the reduction in volume and mass of the compost.

A $\mathrm{C}: \mathrm{N}$ ratio of $30: 1$ before composting is considered desirable. Higher $\mathrm{C}: \mathrm{N}$ ratio causes initial $\mathrm{N}$ immobilization and very low $C: N$ ratio causes overabundance of $\mathrm{N}$, resulting in accumulation of ammonia. The $\mathrm{C}: \mathrm{N}$ ratio decreases during composting, as organic carbon is converted to $\mathrm{CO}_{2}$ by degraders and lost in its gaseous phase, whereas the nitrogen is converted to other forms by organisms. The $\mathrm{C}: \mathrm{N}$ ratio of the test compost was reported to be $22: 1$, suggesting it to be effective for the enhancement of soil fertility. Jeyapriya and Saseetharan (2007) reported a reduction in the $\mathrm{C}: \mathrm{N}$ ratio of MSW from 30:1 to the final compost $C: N$ ratio of 19:1. Jilani (2007) observed a huge reduction in the $\mathrm{C}: \mathrm{N}$ ratio from 40 to 26 during MSW composting (64). A final C:N ratio of less than 26:1 is considered suitable for the compost for its applicability to increase the fertility of soil.
There was a slight increase in the percentage of \#\#\#phosphorus, potassium and sulphur in the test compost as compared to fresh waste. Phosphorus increased from 0.32 to $0.50 \%$, potassium increased from 0.39 to $0.55 \%$ and sulphur increased from 0.02 to $0.10 \%$. Similar results were obtained by Janakrinam and Sridevi (2010), where phosphorus increased from 0.29 to $0.40 \%$ and potassium increased from 1.61 to $1.78 \%$.

\section{Conclusion}

We can conclude from the study that among the two consortia prepared for organic waste degradation, consortium 2 had the highest degrading capability and the compost produced after 30 days of degradation had a dark colour and lacked foul smell. Consortium 2 was consistent in degrading a greater quantity of waste $(30 \mathrm{~kg})$ and can be employed for composting a large quantity of wastes in future. Compost analysis of $30 \mathrm{~kg}$ wastes inoculated with consortium 2 showed $\mathrm{C}: \mathrm{N}$ of $22: 1$ and increased percentage of $\mathrm{K}, \mathrm{P}$ and $\mathrm{S}$ which are required for enhancement of soil fertility. Therefore, we can conclude from this study that consortium 2 can serve as a biological tool for removal of organic solid wastes from the environment and the compost generated from the degradation can be applied to increase the fertility of the soil.

Open Access This article is distributed under the terms of the Creative Commons Attribution 4.0 International License (http://crea tivecommons.org/licenses/by/4.0/), which permits unrestricted use, distribution, and reproduction in any medium, provided you give appropriate credit to the original author(s) and the source, provide a link to the Creative Commons license, and indicate if changes were made.

\section{References}

Alexander M (1977) Introduction to soil microbiology, 2nd edn. Wiley, New York

AWPA (1986) American Wood Preservers Association Standards, Books of standards, Stevensville, Maryland, USA

Bandara NJ, Hettiaratchi JP, Wirasinghe SC, Pilapiiya S (2007) Relation of waste generation and composition to socio-economic factors: a case study. Environ Monit Assess 135(1):31-39. doi:10.1007/s10661-007-9705-3

Bezdicek D, Fauci M, Schwab G (2002) Impacts and management of soil acidity under direct seed system-effects of beneficial soil 
microbes and soil fauna. Direct seed conference. Department of crop and soil sciences, WSU, Pullman, WA

Bremner JM (1960) Determination of nitrogen in soil by the Kjeldahl method. J Agric Sci 55(1):11-33. doi:10.1017/ S0021859600021572

Elango D, Thinakaran N, Pannerselvam P, Sivanesan S (2009) Thermophilic composting of municipal solid waste. Appl Energy 86:663-668. doi:10.1016/j.apenergy.2008.06.009

Forastiere F, Badaloni C, Hoogh KD, Kraus MK, Martuzzi M, Mitis F (2011) Health impact assessment of waste management facilities in three European countries. Environ Health 10:53. doi:10.1186/ 1476-069X-10-53

Gautam SP, Bundela PS, Pandey AK, Jamaluddin AM (2010) Optimization of the medium for the production of cellulase by the Trichoderma viride using submerged fermentation. Int $\mathrm{J}$ Environ Sci 1(4):656-665

Gopinath LR, Christy PM, Mahesh K, Bhuvaneshwari R, Divya D (2014) Identification and evaluation of effective bacterial consortium for efficient biogas production. J Environ Sci Toxic Food Technol 8(3):80-86

Gouveia N, Prado RR (2009) Health risks in areas close to urban solid waste landfill sites. Rev de Saude Publica 44(5):1-8

Gupta B, Arora SK (2016) Municipal solid waste management in Delhi-the capital of India. Int J Innov Res Sci Eng Technol 5(4):5130-5138. doi:10.15680/IJIRSET.2016.0504106

Hibbing ME, Fuqua C, Parsek MR, Peterson SB (2010) Bacterial competition: surviving and thriving in the microbial jungle. Nat Rev Microbiol 8(1):15-25. doi:10.1038/nrmicro2259

Higgins Matthew J, Chen YS, Murthi DP, Sudhir N, Nick A, John T (2006) Cycling of volatile organic sulfur compounds in anaerobically digested biosolids and its implications for odours. Waste Environ Res 78(3):243-252

Jackson ML (1973) Soil Chemical Analysis, 1st edn. Prentice Hall of India Pvt. Ltd., New Delhi, India

Janakrinam T, Sridevi K (2010) Conversion of waste into wealth: a study in solid waste managent. Electron J Chem 7(4):1340-1345. doi:10.1155/2010/549185

Jeyapriya SP, Saseetharan MK (2007) Study on municipal solid waste reuse characteristics and leachate samples of Coimbatore city. J Nat Environ Pollut Technol 6(1):149-152

Jilani S (2007) Municipal solid waste composting and its assessment for reuse in plant production. Pak J Bot 39(1):271-277

Lim PN, Wu TY, Sim EYS, Lim SL (2011) The potential reuse of soybean husk as feed stock of Eudrilus eugeniae in vermicomposting. J Sci Food Agric 91(14):2637-2642. doi:10.1002/jsfa. 4504

Lim SL, Lee LH, Wu TY (2016) Sustainability of using composting and vermicomposting technologies for organic solid waste biotransformation: recent overview, greenhouse gases emissions and economic analysis. J Clean Prod 111:262-278. doi:10.1016/ j.jclepro.2015.08.083

Meuser H (2010) Contaminated urban soils, 1st edn. Springer, Verlag, $\mathrm{UK}, \mathrm{p} 318$

Meuser H, Grewal KS, Anlauf R, Malik RS, Narwal RK, Saini J (2011) Physical composition, nutrients and contaminants of typical waste dumping sites. Am J Environ Sci 7(1):26-34. doi:10.3844/ajessp.2011.26.34

Mirdamadian SH, Khayam-Nekoui SM, Ghanavati H (2011) Reduce of fermentation time in composting process by using a special microbial consortium. World Acad Sci Eng Technol 52:475-479
Pillai S, Peter AE, Sunil BM, Shrihari S (2014) Soil pollution near a municipal soil waste disposal site in India. International conference on biological, civil and environmental engineering (BCEE-2014), pp 148-152, Dubai (UAE), 17-18 Mar 2014. doi:10.15242/IICBE.C0314080

Raju EV, Divakar G (2013) Production of pectinase by using Bacillus circulans isolated from dump yards of vegetable wastes. Int $\mathrm{J}$ Pharm Sci Res 4(7):2615-2622. doi:10.13040/IJPSR.0975-8232. 4(7).2615-22

Rawat M, Singh UK, Mishra AK, Subramaniam V (2008) Methane emission and heavy metals quantification from selected landfill areas in India. Environ Monit Assess 67(74):137. doi:10.1007/ s10661-007-9729-8

Saha A, Santra SC (2014) Isolation and characterization of bacteria isolated from municipal solid waste for production of industrial enzymes and waste degradation. J Microbiol Exp 1(1):1-8. doi:10.15406/jmen.2014.01.00003

Sarkar P, Meghvanshi M, Singh R (2011) Microbial consortium: a new approach in effective degradation of organic kitchen wastes. Int J Environ Sci Dev 2(3):170-174

Shamaini K, Fauzia SH (2014) Enhanced vermicomposting for combination of organic waste through subsequent treatment with selected microorganisms. J Microbiol Res 4(2):54-67

Singh A, Sharma S (2003) Effect of microbial inoculation on mixed solid waste composting, vermicomposting and plant response. Comp Sci Util 11(3):190-199

Tambone F, Genevini P, Adani F (2013) The effects of short-term compost application on soil chemical properties and on nutritional status of maize plant. Compost Sci Util 15(3):176-183

Tejada M, Gonzalez JL (2007) Influence of organic amendments on soil structure and soil loss under stimulated rain. Soil Tillage Res 93(1): 197-2305

Tom AP, Pawels R, Haridas A (2016) Biodrying process: a sustainable technology for treatment of municipal solid waste with high moisture content. Waste Manag 49:64-72. doi:10. 1016/j.wasman.2016.01.004

Toth S, Prince AL (1949) Estimation of cation-exchange capacity and exchangeable $\mathrm{Ca}, \mathrm{K}$, and $\mathrm{Na}$ contents of soils by flame photometric techniques. Soil Sci 67(6):439-446

van Hamme JD, Singh A, Ward OP (2003) Recent advances in petroleum microbiology. Microbiol Mol Biol Rev 67(4):503-549. doi:10.1128/MMBR.67.4.503-549.2003

Visilind PA, Spinosa L (2001) Production and Regulations. In: Spinosa L, Visilind IA (eds) Sludge into biosolids: processing, disposal, utilization. IWA Publishing, London, pp 3-18

Walkey A, Black IA (1934) An examination of the Degtjareff method for determining soil organic matter and a proposed modification of the chromic acid titration method. Soil Sci 37(1):29-38

Wu TY, Lim SL, Lim PN, Shak KPY (2014) Biotransformation of biodegradable solid wastes into organic fertilizers using composting or/and vermicomposting. Chem Eng Trans 39:1579-1584. doi:10.3303/CET1439264

\section{Publisher's Note}

Springer Nature remains neutral with regard to jurisdictional claims in published maps and institutional affiliations. 